\title{
Primary haemangiopericytoma of lung
}

\author{
J.B. MEA DE, F. WH ITWELL, B. J. B I CK F O R D, \\ and J.K. B. W A D D I G TON \\ Cardio-thoracic Surgical Centre, Broadgreen Hospital, Thomas Drive, Liverpool L14 3LB
}

\begin{abstract}
Meade, J. B., Whitwell, F., Bickford, B. J., and Waddington, J. K. B. (1974). Thorax, 29, 1-15. Primary haemangiopericytoma of lung. Haemangiopericytoma is a rare neoplasm which may occur at any age and arise in almost any part of the body. At least 247 examples have been reported in the world literature, but only 24 appear to have arisen primarily in the lung. A summary of the features of these cases, collected from the literature, is presented, and four additional cases are described. The tumour may be innocent or malignant, but there are no characteristic clinical or radiological features to distinguish it from other neoplasms of the lung. Because of uncertainty as to diagnosis and prognosis, surgical excision appears to be the treatment of choice. In the whole series of 28 cases, rather more than half (16) were female, and they tended to be older than the male patients. The mortality from recurrence was higher in males than in females (50\% compared with $32 \%)$. The prognosis in general seems to be best with small, asymptomatic tumours, especially in female patients. A brief account is given of the nature and function of the pericyte. It was originally thought to be a cell of muscular type, but recent research suggests that it is a multipotent cell capable of development into other cell types and having phagocytic properties. It lies in the basement membrane of capillary blood vessels and may have some connection with antibody formation, but its exact function has not yet been elucidated.
\end{abstract}

The name haemangiopericytoma was suggested by Stout and Murray (1942) for an unusual vascular tumour composed of capillary pericytes. The tumour is ubiquitous in its occurrence yet only a small number of primary pulmonary haemangiopericytomas have been reported in the world literature. We present four cases of primary haemangiopericytoma of lung together with a review of the world literature.

\section{CASE REPORTS}

CASE 1 A 73-year-old professional man was admitted to Broadgreen Hospital in October 1969. He complained of recent sudden onset of dyspnoea and cough. Physical examination suggested the presence of a large right-sided pleural effusion. Repeated aspirations of fluid to a total volume of 7 litres were performed. Examination of the fluid failed to demonstrate the presence of malignant cells. A post-aspiration chest radiograph (Fig. 1) revealed a large mass in the right lower lobe. Bronchoscopy was not helpful in making a diagnosis.

A right pneumonectomy was performed. The right lung contained a large firm lobulated mass which protruded through the pleura in the posterior part of the upper lobe.
On section of the lung the tumour was found to replace the central part of the lung involving all lobes and measuring $15 \times 8 \times 7 \mathrm{~cm}$ across (Fig. 2). It had a firm texture, appeared encapsulated, and was light grey except for areas of haemorrhage and necrosis. No connection could be found between the tumour and any large bronchus or pulmonary vessel, except at one area in the periphery of the upper lobe where the tumour involved a medium-sized pulmonary vein and extended into its lumen. The hilar and subcarinal lymph nodes were not involved by the tumour, which had the typical appearance of a malignant haemangiopericytoma.

Convalescence was complicated by pain in the right calf which was attributed to deep vein thrombosis and responded rapidly to anticoagulant therapy. The patient was allowed home during the third postoperative week. Two months later he developed a local metastasis in the thoracotomy scar and a small painful nodule in the right calf. This latter lesion was excised and proved to be a metastasis from the haemangiopericytoma. A course of radiotherapy was given to the right leg but the patient died five months after the pneumonectomy.

CASE 2 A 53-year-old engineering worker was first admitted to Broadgreen Hospital in July 1970 . He had suffered from chronic bronchitis for many years but 


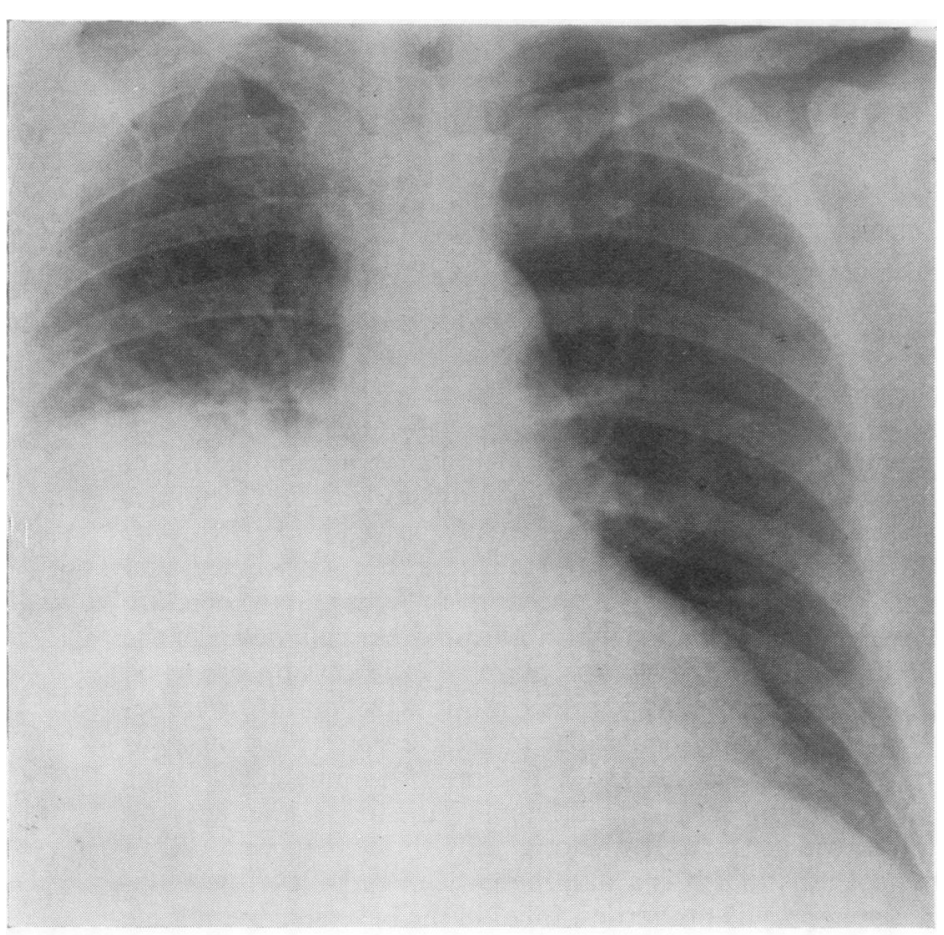

(a)

FIG. 1. Case 1. Postero-anterior (a) and lateral (b) chest radiographs showing tumour in the right lower lobe.

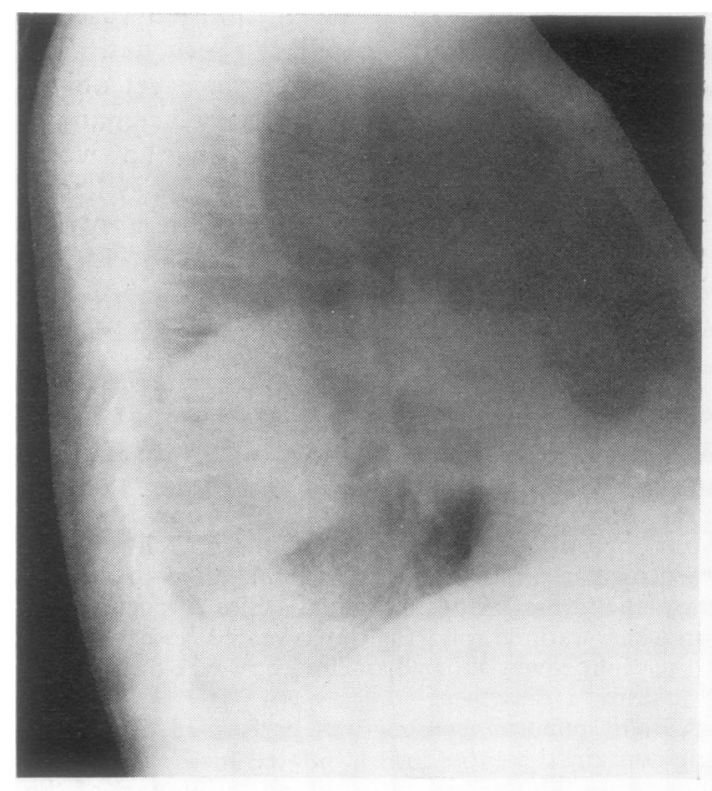




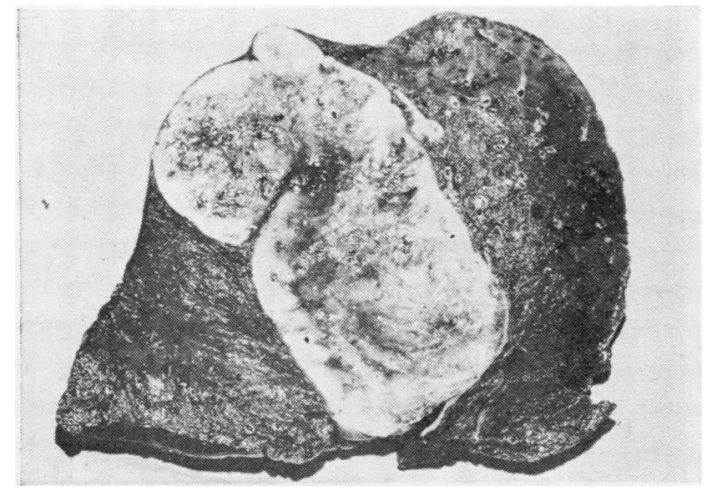

FIG. 2. Case 1. Right lung containing large encapsulated tumour.

two weeks before admission he complained of sudden onset of cough and haemoptysis associated with pleuritic type chest pain. Air entry was absent over the upper lobe. A chest radiograph (Fig. 3) revealed the presence of a large tumour in the left upper lobe. Bronchoscopy was not helpful in making a diagnosis.
Left pneumonectomy was performed. The left lung showed a bulky upper lobe containing a central tumour and a normal lower lobe. The cut surface of the upper lobe showed it to be largely replaced by a rounded encapsulated tumour $14 \mathrm{~cm}$ across. The tumour showed no involvement of large bronchi or pulmonary vessels but it extended to the visceral pleura, which it did not penetrate. The cut surface was firm and creamcoloured except for areas of necrosis and haemorrhage.

The histology showed the typical structure of a malignant haemangiopericytoma.

Convalescence was without complications and the patient was discharged on the 17 th postoperative day.

The patient was re-admitted to hospital on 22 September, 1970, because of painful abdominal distension and dysuria. He died ten days later.

Necropsy revealed that the diaphragm and left chest wall were directly invaded by tumour. Beneath the left dome of the diaphragm was a cystic mass whose wall was partly formed by the spleen. This mass was also directly invaded by tumour. There were several pints of ascitic fluid in the peritoneal cavity. There were multiple metastases in the right lobe of the liver and in the tail of the pancreas. Deposits were also present in the mesentery, obstructing the sigmoid colon.

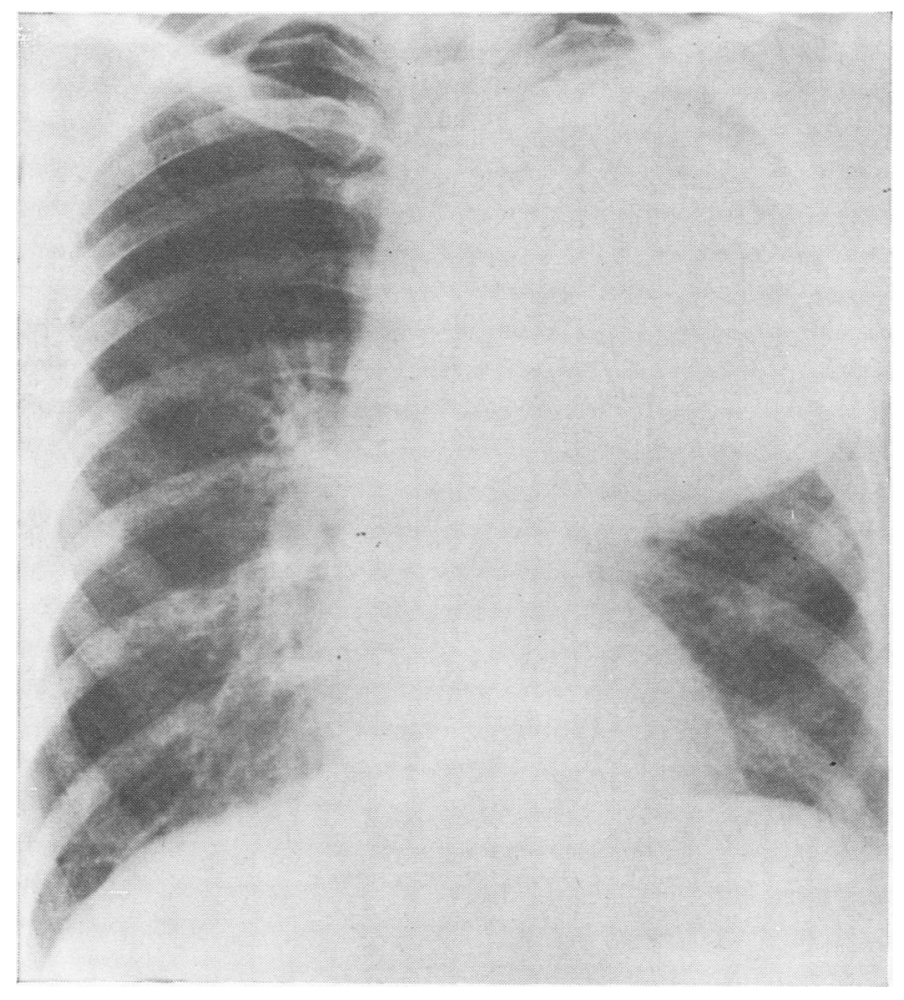

FIG 3 (a) Legend overleaf. 
FIG. 3. Case 2. Postero-anterior (a) and lateral (b) chest radiographs showing tumour in left upper lobe.

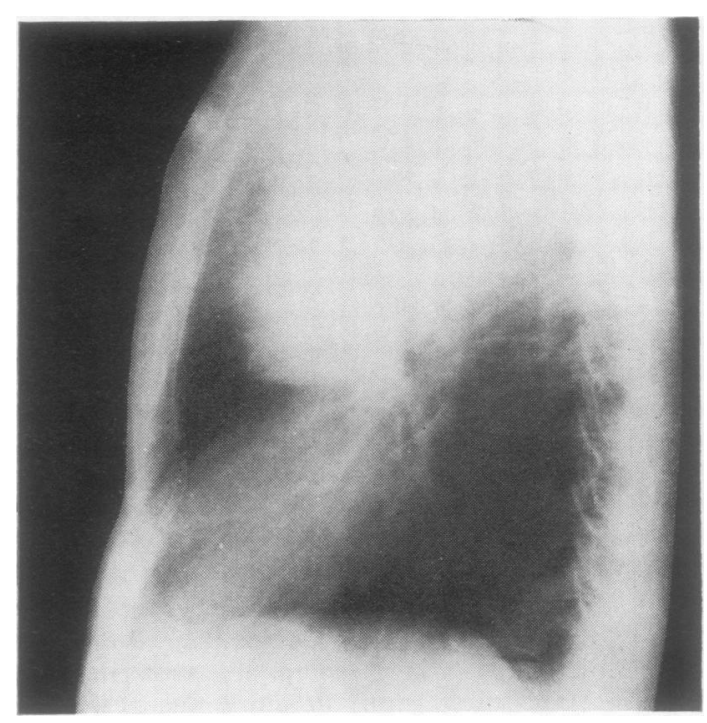

FIG. $3(b)$

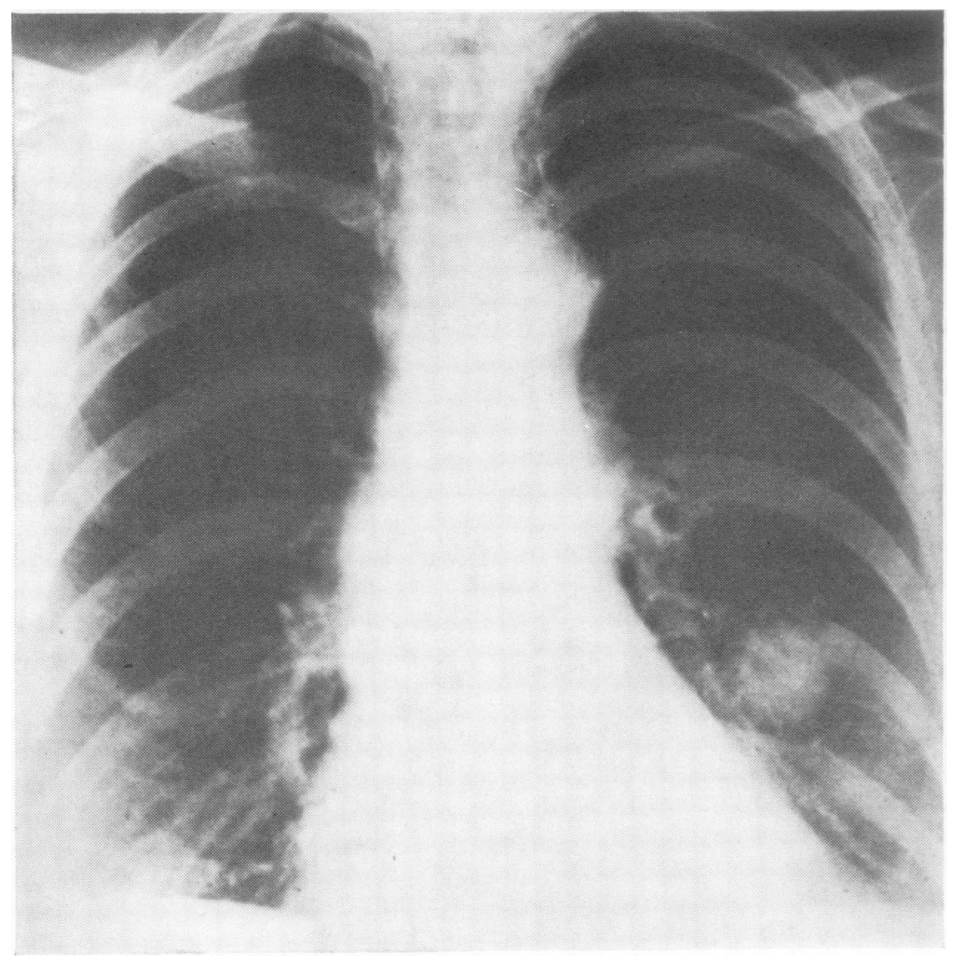

FIG. 4 (a) Legend opposite. 


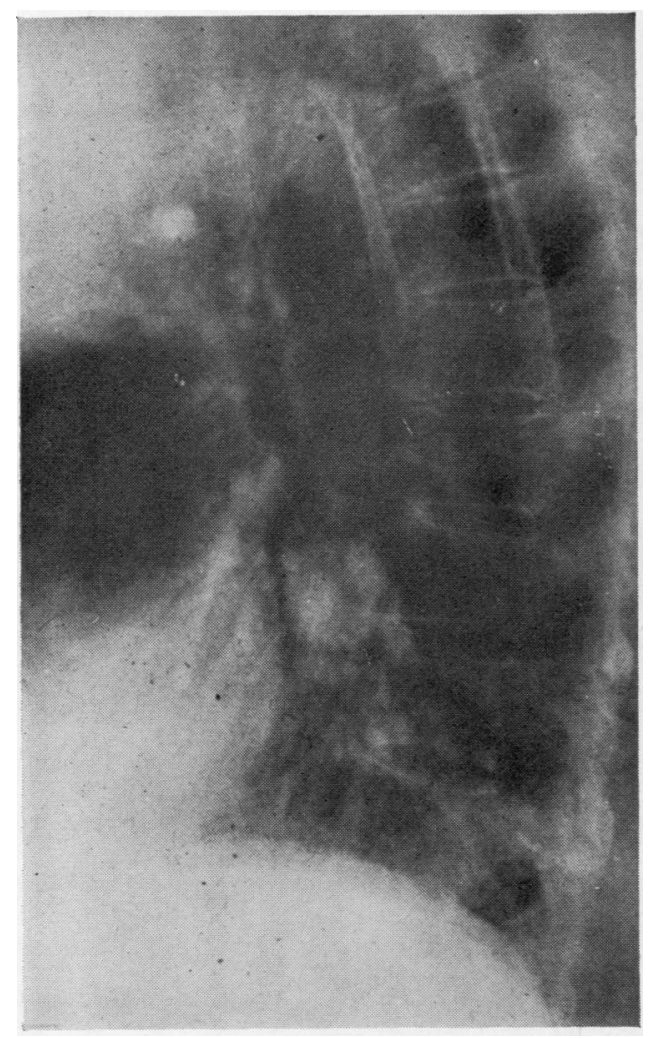

FIG. $4(b)$

FIG. 4. Case 3. Postero-anterior (a) and lateral (b) chest radiographs showing small tumour in the left lower lobe.

CASE 3 A 63-year-old woman underwent a cholecystectomy in January 1955 at the Manchester Royal Infirmary. A chest radiograph (Fig. 4) performed as part of a series of investigations for a postoperative pyrexia revealed a small round opacity in the left lower lobe. There were no symptoms referable to this lesion. A thoracotomy was performed with the intention of removing the left lower lobe but the lesion enucleated so easily that lobectomy was not deemed necessary. The patient was well three years later at which time she was lost to follow-up. The histological appearances of the tumour were those of a haemangiopericytoma.

CASE 4 A 70-year-old man was admitted to Abergele Hospital in June 1972. He complained of left-sided chest pain and cough. Air entry was absent over the left upper lobe. A chest radiograph (Fig. 5) showed a large mass in the left upper lobe.

A left pneumonectomy was performed. The left lung showed the upper lobe to be largely replaced by a firm rounded encapsulated tumour, about $14 \times 12 \times 10$ $\mathrm{cm}$ across. There was no involvement of hilar struc- tures but the tumour penetrated the lateral pleural membrane. The cut surface showed extensive areas of haemorrhage and necrosis. Microscopically it was a malignant haemangiopericytoma.

Convalescence was uncomplicated. A course of radiotherapy was given to the left chest wall as the tumour had been adherent to the anterior chest wall. The patient died four months later.

\section{PATHOLOGICAL FEATURES}

GROSS APPEARANCES These cases illustrate the features usually found in pulmonary haemangiopericytomata, the tumours being large and usually centrally situated, though they often reach to the visceral pleura. They are well encapsulated, though the capsule may not be complete, and the surrounding lung tissue shows no sign of compression collapse.

At first glance they look like carcinoid bronchial adenomas, but they are usually larger, extend deeper into the lung substance, and they have no bronchial origin. The texture and colour are similar to those of a bronchial adenoma except for the much more extensive areas of haemorrhage and necrosis.

MICROSCOPIC FEATURES The tumour is characterized microscopically by its vascularity and the peritheliomatous arrangement of the tumour cells. This vascularity comes as rather a surprise because, except for the areas of haemorrhage, the naked-eye appearance is remarkably bloodless. The explanation of this is probably that many of the vascular channels are empty of blood.

However, other lung tumours may show a peritheliomatous pattern, including some carcinomas, carcinoid adenomas, glomangiomas, angiosarcomas, and chemodectomas, and it is the intimate relationship of the fine reticulin fibres and fibrils around the vascular channels and the tumour cells which is most helpful in the diagnosis.

In haematoxylin and eosin stained sections the well preserved vascular channels are surrounded by sheets of regular cells which have pale cytoplasm and large vesicular nuclei (Figs 6 and 7). The cells are rounded or may be spindle-shaped and they show few mitoses. Silver impregnation shows a fine reticulin network radiating from the vascular channels (Figs 8 and 9) and encircling small groups of tumour cells (Fig. 10).

This pattern extends through much of the tumour tissue but in places the picture is less clearly seen, with irregular tumour cells, including giant cells, and many mitoses and some loss of the reticulin pattern (Fig. 11). 


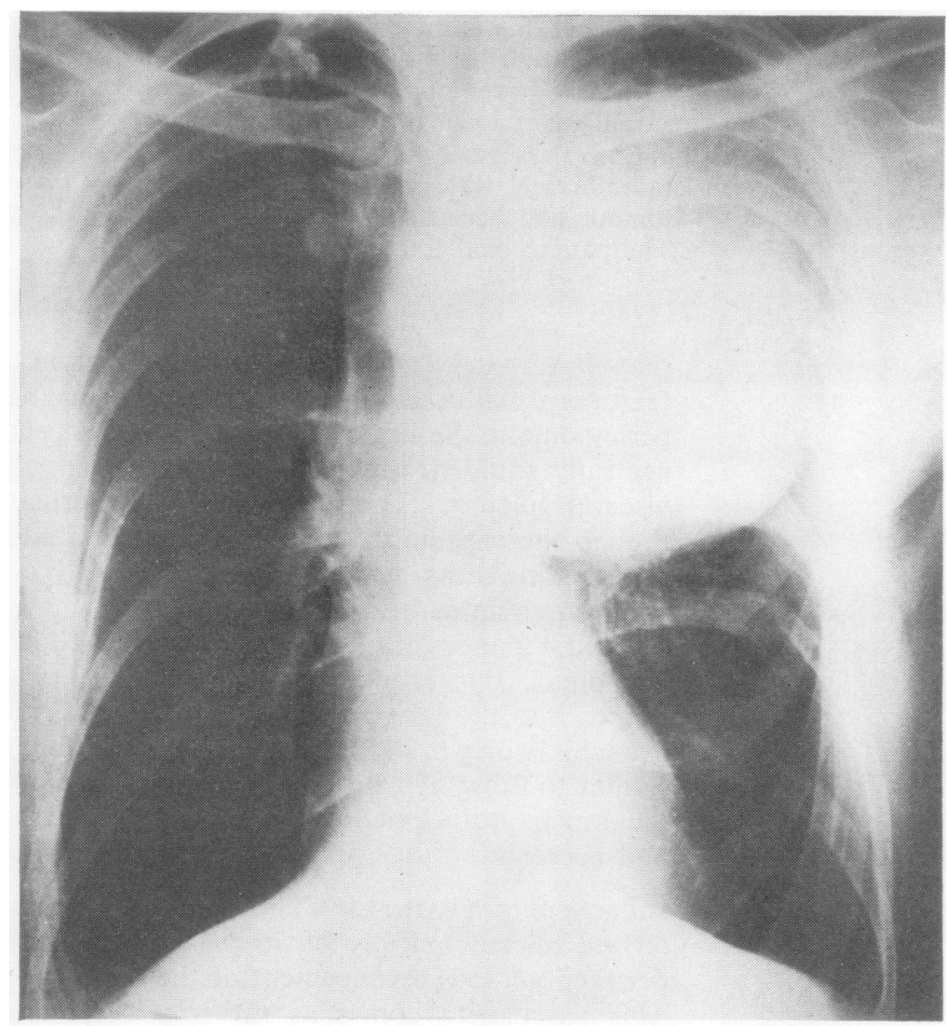

(a)

FIG. 5. Case 4. Postero-anterior (a) and lateral (b) chest radiographs showing large tumour in left upper lobe.

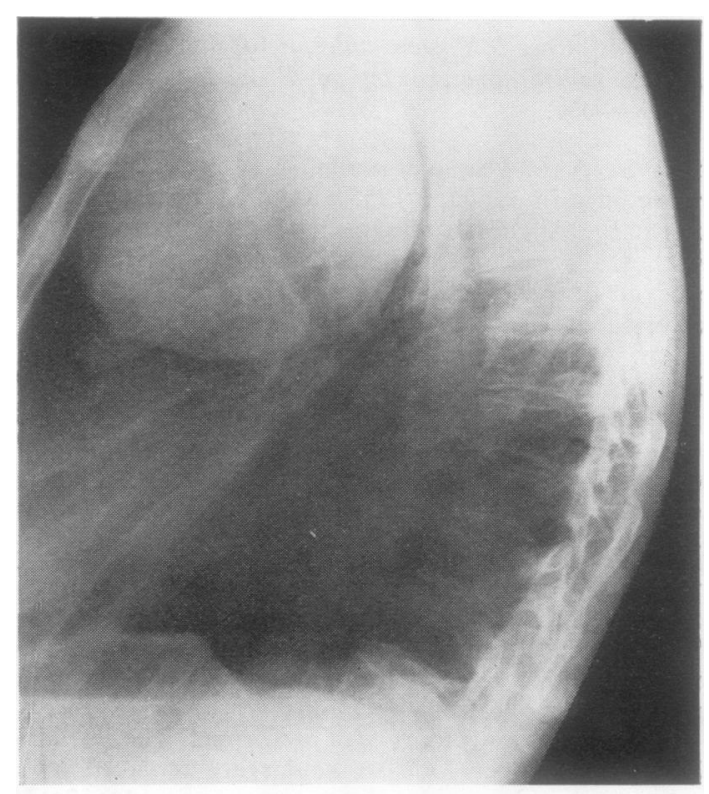

(b) 


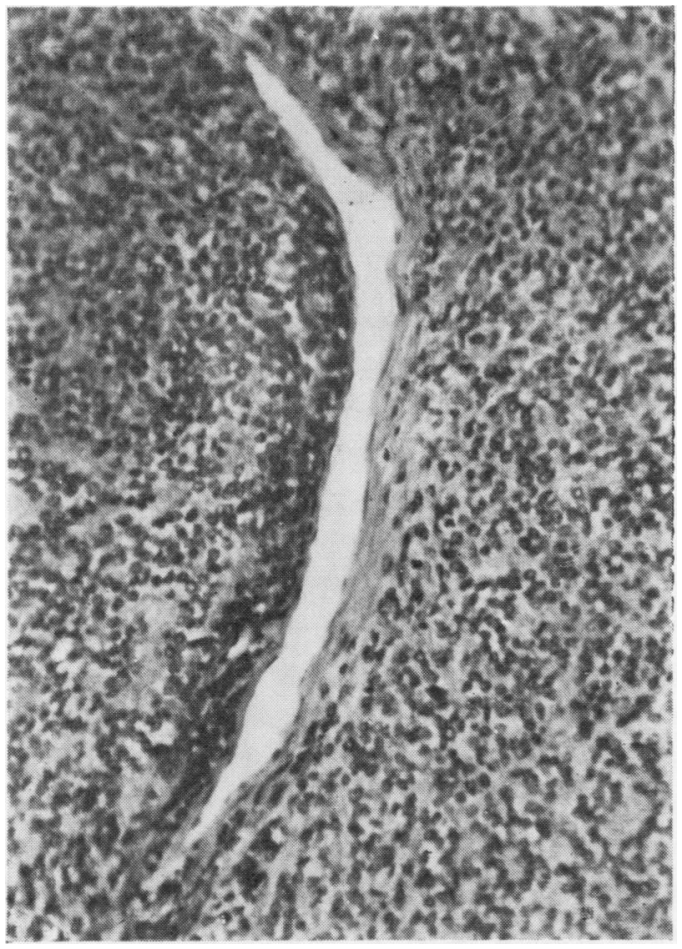

FIG. 6. Case 1. Tumour around vascular channel, which is not invaded or damaged. Haematoxylin and eosin $\times 200$.

FIG. 7. Case 1. High-power view of area of Fig. 6 showing endothelial lining of vascular channel and regular vesicular tumour nuclei. Haematoxylin and eosin $\times 670$. 


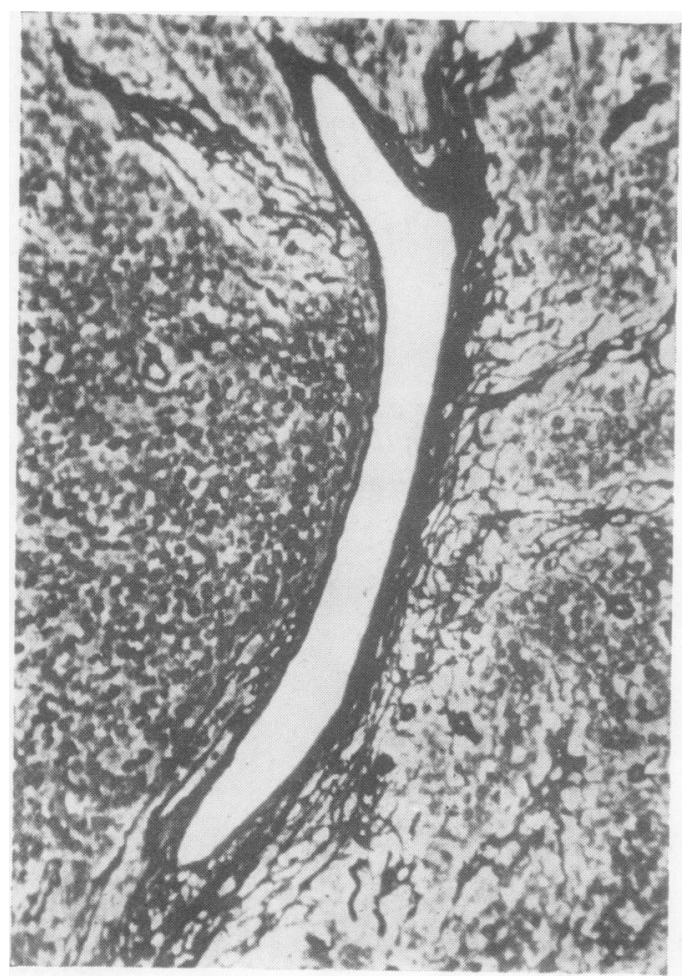

FIG. 9. Case 2. Gomori silver impregnation, showing reticulin fibrils radiating from vascular channel. $\times 300$.
FIG. 8. Case 1. Same field as in Fig. 6. Gomori silver impregnation, showing reticulin fibrils around vascular channel. $\times 200$.

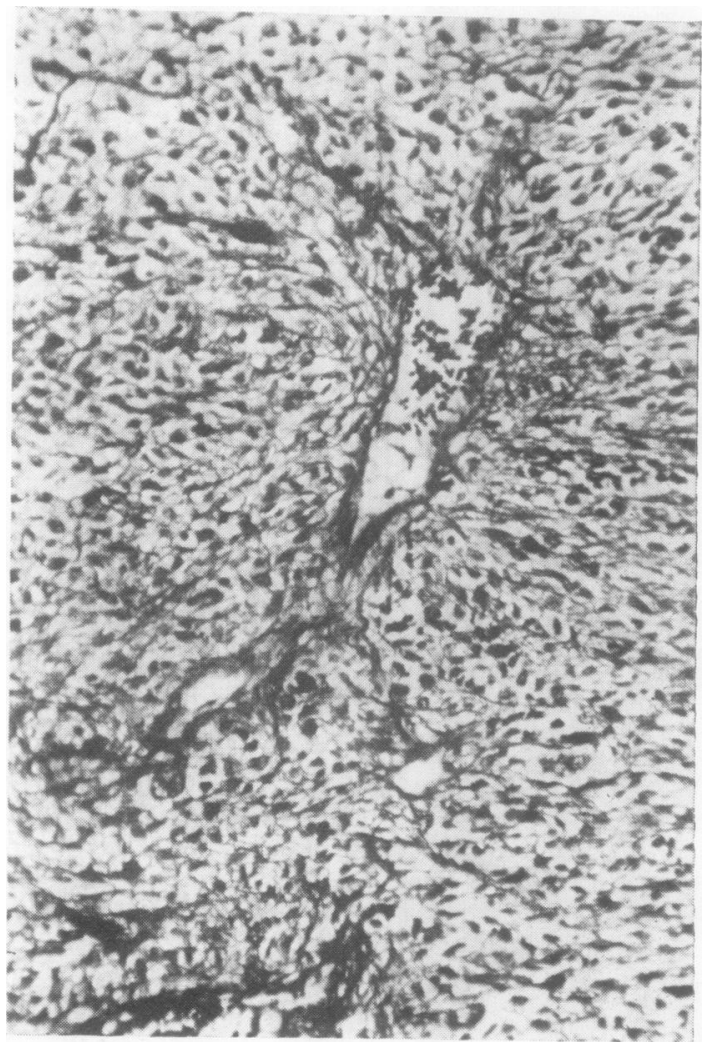


FIG. 10. Case 1. Same field as in Fig. 7 showing reticulin fibrils forming a network around small groups of tumour cells. Gomori silver impregnation. $\times 760$.
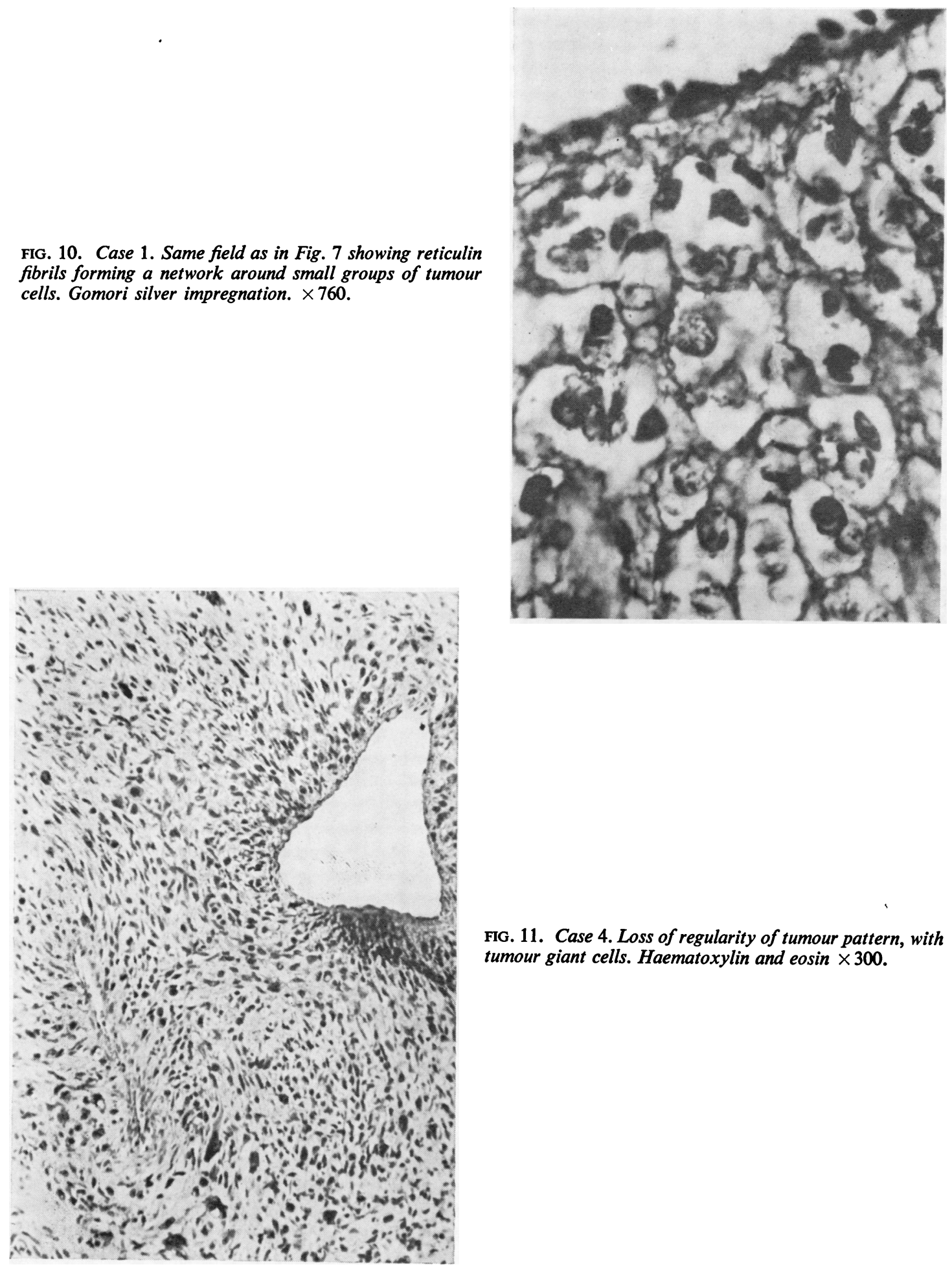

FIG. 11. Case 4. Loss of regularity of tumour pattern, with tumour giant cells. Haematoxylin and eosin $\times 300$. 
FIG. 12. Case 4. Loss of regularity of tumour pattern, with tumour giant cells and extensive necrosis. Haematoxylin and eosin $\times 300$.
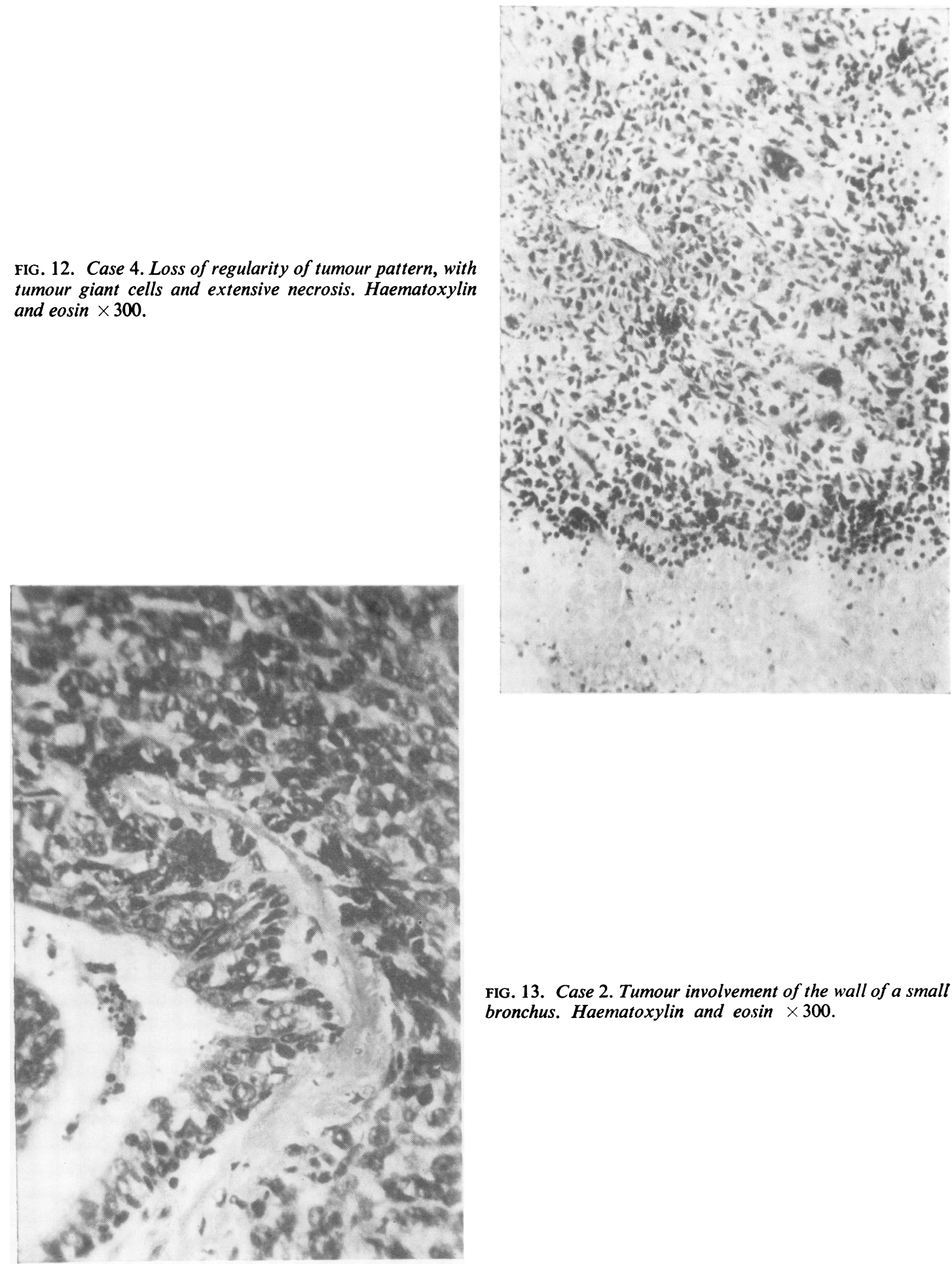

FIG. 13. Case 2. Tumour involvement of the wall of a small bronchus. Haematoxylin and eosin $\times 300$. 
Necrosis is found in tumour tissue away from the vascular channels (Fig. 12) but also where these vessels are thrombosed. The haemorrhages occur from the damaged channels and more often in the less well differentiated areas.

Microscopic involvement of bronchi (Fig. 13) and pulmonary vessels occurs, and it is often difficult to decide whether a pulmonary haemangiopericytoma is a primary or a secondary neoplasm.

\section{STRUCTURE, ORIGIN AND FUNCTION OF THE PERICYTE}

Stout and Murray (1942) originally suggested that the haemangiopericytoma was composed of capillary pericytes. This observation has since been confirmed by the electron microscopic studies of Murad, von Haam, and Murthy (1968), Fisher, Kaufman, and Mason (1952), and Kuhn and Rosai (1969). Movat and Fernando (1964) noted the lack of basement membrane around pericytes forming the tumour.

The pericyte has evoked much controversy during the past century. Eberth (1871) was probably the first to describe the cell. Rouget (1873, 1874) described 'non-pigmented adventitial cells'; Vimtrup (1922) referred to them as 'Rouget's cells'. Zimmermann (1923) called the cells 'pericytes' in a paper which presented the results of some 40 years' study. He described the pericytes as 'reminiscent of a hand with slightly spread fingers, which is gripping the other arm'. This was to illustrate a cell body from which emerged primary appendages which in turn gave rise to a series of secondary appendages. Benninghoff (1930) confirmed these findings.

Recent electron microscopic studies, in particular those of Fernando and Movat (1964), Kuwabara and Cogan (1963), Cotran, Gattuta, and Majno

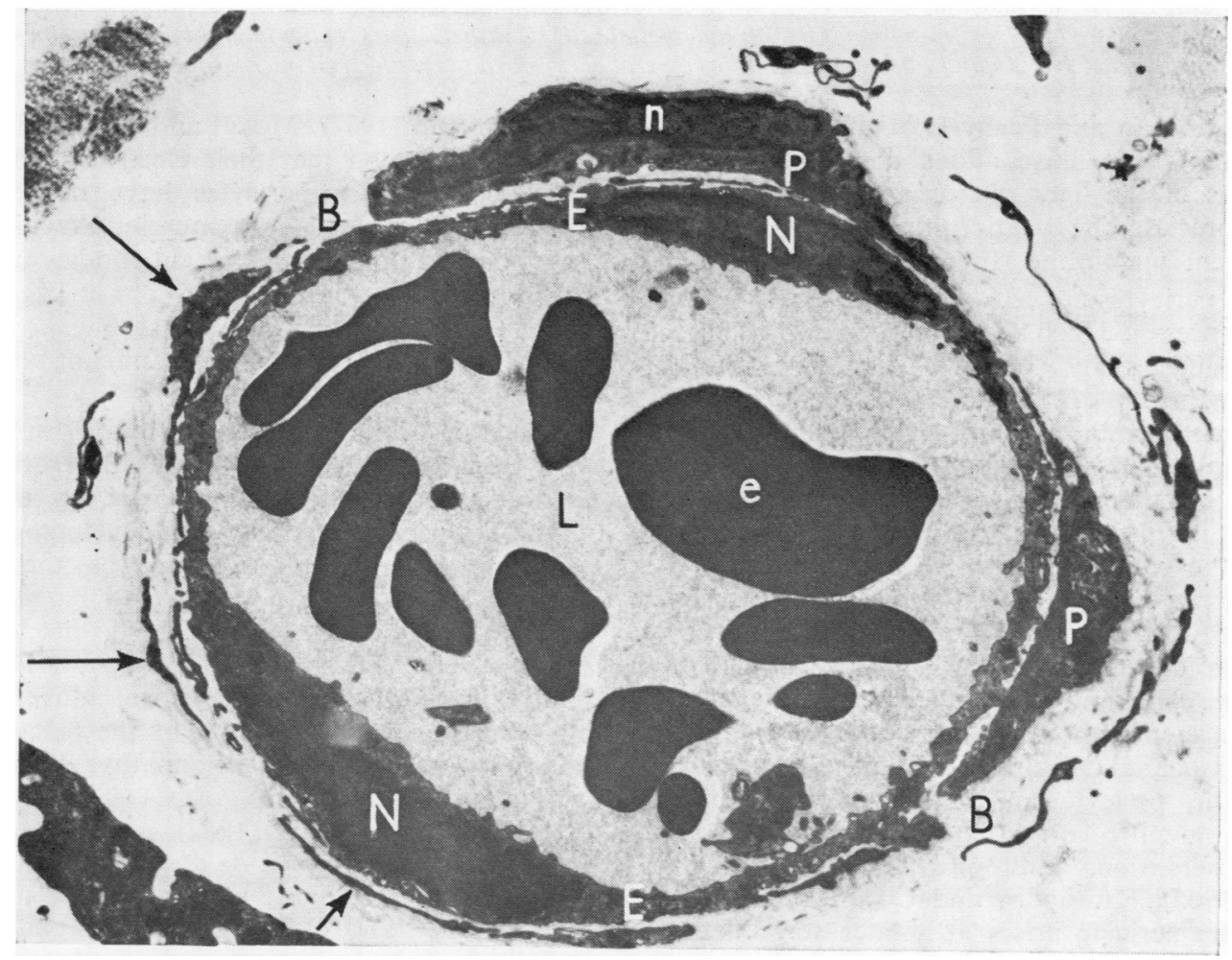

FIG. 14. Transverse section of subcutaneous capillary of a rat. The lumen $(L)$ contains several erythrocytes $(e)$. The wall is composed of two endothelial cells $(E)$, each of which contains a nucleus $(N)$. The endothelial cells lie on a dark, granular basement membrane $(B)$ which divides to enclose a pericyte $(P)$. The pericyte contains a nucleus (n) and cyptoplasmic processes (arrows) which encircle the capillary. Electron micrograph $\times 5,650$. 


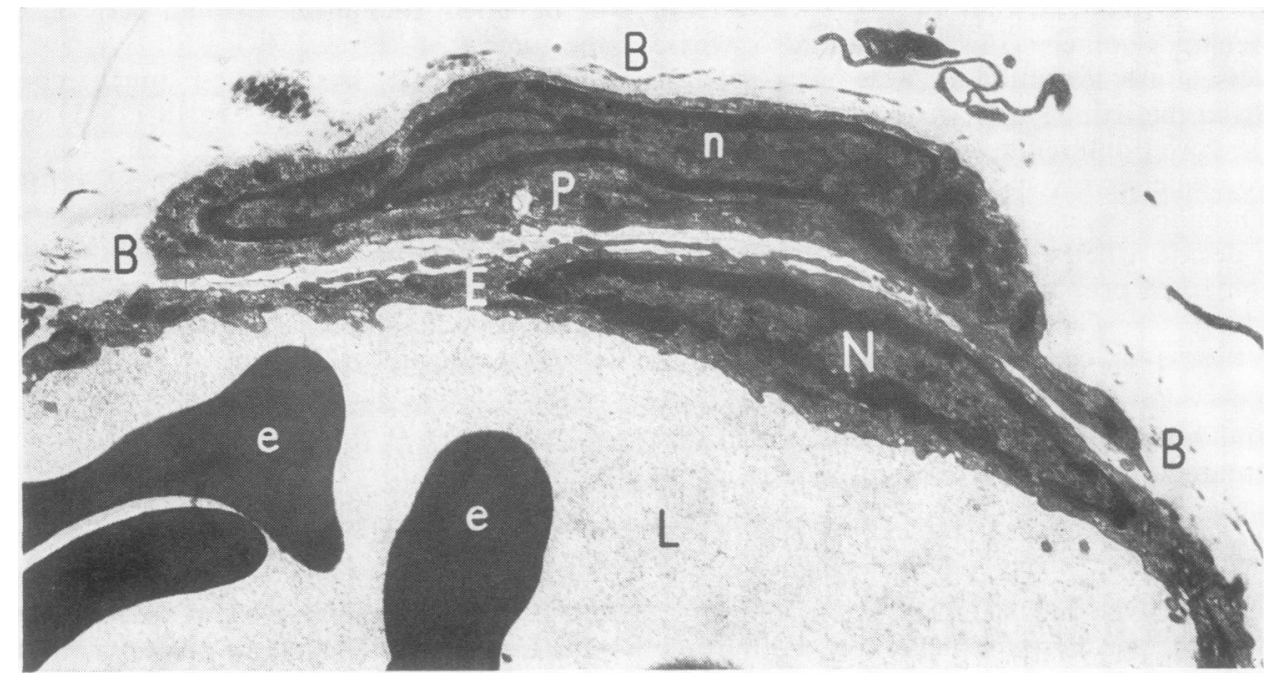

FIG. 15. Higher magnification of Fig. 14. The pericyte $(P)$ contains a nucleus $(n)$ and lies within the granular capillary basement membrane $(B)$. An endothelial cell $(E)$ with nucleus $(N)$ lies internal to the basement membrane. The capillary lumen $(L)$ contains several erythrocytes $(e)$. Electron micrograph $\times 9,450$.

(1965), Hogan and Feeny (1963) and Ashton and Oliveira (1966), have added considerably to the findings of the light microscopists and enable us to appreciate the relationship of the cell to the basement membrane (Figs 14 and 15).

The pericytes are cells with ramifying protoplasmic processes which surround the endothelial cells of capillaries and venules. They lie within the compartments of the basement membrane. The basement membrane is not a simple membrane but a complex series of compartments which communicate with one another by small stomata, thus permitting fluid, cells, and small particles to move from the vessel lumen to the extracapillary space. The pericyte layer is continuous with the smooth muscle layer of the arterioles but the pericytes contain considerably fewer fibrils than smooth muscle cells and the attachment zones at the plasma membrane are less prominent.

Shakib and Oliveira (1966) are of the opinion that the pericyte and endothelial cell have a common cell of origin and they are supported by the observations of Bloodworth (1963) and Agrawal (1965). Kuwabara and Cogan (1963) believe that the pericyte arises at a later stage than the endothelial cell.

The function of the pericyte remains a matter of controversy. Rouget (1879) was the first to suggest a role like that of the smooth muscle of the arteriole. This has been supported by Vimtrup (1922), Bensley and Vimtrup (1928), and Krogh and Vimtrup (1932). Movat and Fernando (1964), however, contend that their electron microscopic studies show that pericytes have none of the characteristics of smooth muscle; they have no myofibrils and no attachment bodies and the arrangement of the organelles is not like that of the smooth muscle. They suggest that the pericyte plays a part in phagocytosis and antibody production.

Another view, that the pericyte is a multipotent cell capable of developing into other cells and that it is phagocytic, is supported by the early observations of Marchand (1898), Herzog (1914), and Maximov (1927). We believe that the electron microscopic studies of Majno and Palade (1961) illustrate beautifully the phagocytic properties of the pericyte. Kuwabara and Cogan (1963) suggested that pericytes inhibit neovasculogenesis but Oliveira (1966), in his study of the behaviour of the pericyte in diabetic retinopathy, did not substantiate this.

Murray and Stout (1942) and Stout (1956) suggested that the pericyte was the cell of origin of the glomus tumour, but the recent studies of Toker (1969) and of Venkatachalam and Greally (1969) do not support this opinion. In their view the cell of the glomus tumour is a modified smooth muscle cell and not a pericyte. Murad et al. (1968) studied a haemangiopericytoma and a glomus tumour using the electron microscope and confirmed that the haemangiopericytoma is com- 
posed of pericytes while the glomus tumour cells resemble those of vascular smooth muscle.

\section{CLINICAL FEATURES}

Twenty-one examples of primary haemangiopericytoma of lung in adults have been collected from the world literature. Details of these patients, together with those of the four patients reported here, are presented in the table. Sixteen of the patients $(64 \%$ of the total) were female. The age range of the female patients was 37 to 71 years giving an average age of 50.5 years. The range for male patients was 18 to 73 years with an average age of 43 years. Backwinkel and Diddams (1970), reviewing 247 cases of haemangiopericytoma in all regions of the body, found a female incidence of $50 \%$ with a fairly even distribution over all age groups from the neonatal period to over 60 years.

All students of this tumour have been impressed by its lack of uniformity in appearance and growth. The table shows variation in size from 2 to $15 \mathrm{~cm}$ in diameter. Cases 10 and 18 are rare examples of multiple primary haemangiopericytomatosis.

Nine of the 16 female patients $(56 \%)$ and three of the nine male patients $(33 \%)$ were without symptoms when the tumour was first discovered. Cough, haemoptysis, and chest pain were the commonest symptoms but these might be associated with any tumour of the lung. There were no clinical features which would aid preoperative tumour type diagnosis. Radiographic appearances were likewise unhelpful in this respect.

Three cases of primary haemangiopericytoma of the lung (cases 26, 27, and 28) have been reported in adolescents. A case previously reported as a primary tumour of the lung (Equen, Roach, and Brown, 1963) has, on further examination, proved to be a primary tumour of the rib (Roach, 1971).

Kauffman and Stout (1960) collected 31 cases of primary haemangiopericytoma occurring in children under 15 years. Nineteen were boys and 12 were girls. There appeared to be a higher incidence of malignancy in the older children than in the younger age groups.

Hypoglycaemia and hypertension have been reported in association with haemangiopericytoma. Paullada et al. (1968) have studied one case with hypoglycaemia which they attributed to hyperutilization of glucose by the tumour. Robertson, Klidjian, Harding, and Walters (1967) report a patient with hypertension who was found to have a small haemangiopericytoma in the kidney. The tumour was removed and bioassay showed beyond doubt the presence of renin in large quantities in the tumour. This subject has recently been reviewed (Lee, 1971). There is no evidence at present of the association of any 'endocrine syndrome' with a primary haemangiopericytoma of the lung.

T A B $=\mathrm{E}$

\begin{tabular}{|c|c|c|c|c|c|c|c|}
\hline \multicolumn{2}{|c|}{ Age/Sex } & Symptoms & Site & Size $(\mathrm{cm})$ & Treatment & Outcome & Source \\
\hline $\begin{array}{l}43 \\
38 \\
51 \\
49 \\
37 \\
43 \\
43 \\
71 \\
30 \\
62 \\
43 \\
46 \\
30 \\
66 \\
38 \\
64 \\
46 \\
51 \\
18\end{array}$ & $\begin{array}{l}\mathbf{F} \\
\mathbf{M} \\
\mathbf{M} \\
\mathbf{F} \\
\mathbf{F} \\
\mathbf{F} \\
\mathbf{F} \\
\mathbf{F} \\
\mathbf{M} \\
\mathbf{F} \\
\mathbf{F} \\
\mathbf{F} \\
\mathbf{M} \\
\mathbf{F} \\
\mathbf{F} \\
\mathbf{F} \\
\mathbf{F} \\
\mathbf{F} \\
\mathbf{M}\end{array}$ & $\begin{array}{l}\text { Asymptomatic } \\
\text { Haemoptysis (13 yr) } \\
\text { Dyspnoea, haemoptysis } \\
\text { Asymptomatic } \\
\text { Chest pain, dyspnoea } \\
\text { Haemoptysis } \\
\text { Chest pain (15 yr) } \\
\text { Chest pain } \\
\text { Asymptomatic } \\
\text { Haemoptysis } \\
\text { Asymptomatic } \\
\text { Asymptomatic } \\
\text { Asymptomatic } \\
\text { Asymptomatic } \\
\text { Haemoptysis } \\
\text { Asymptomatic } \\
\text { Chest pain, haemoptysis } \\
\text { Asymptomatic } \\
\text { Chest pain, haemoptysis }\end{array}$ & $\begin{array}{l}\text { RUL } \\
\text { RLL } \\
\text { RLL } \\
\text { RUL } \\
\text { RUL } \\
\text { RLL } \\
\text { LLL } \\
\text { Left lung } \\
\text { LUL } \\
\text { Multiple } \\
\text { LUL } \\
\text { RLL } \\
\text { LLL } \\
\text { RML } \\
\text { LLL } \\
\text { RLL } \\
\text { RLL } \\
\text { Multiple } \\
\text { LLL }\end{array}$ & \begin{tabular}{|c|} 
\\
8 \\
'Apple' \\
2 \\
Fist $\times 2$ \\
'Orange' \\
$\overline{5}$ \\
$5 \cdot 5$ \\
2 \\
14 \\
$2 \cdot 5$ \\
$2 \cdot 5$ \\
'Apple' \\
5 \\
4 \\
5 \\
6 \\
$\frac{1}{\text { Mandarin }}$
\end{tabular} & $\begin{array}{l}\text { Resection } \\
\text { Pneumonectomy } \\
\text { Pneumonectomy } \\
\text { Lobectomy } \\
\text { Pneumonectomy } \\
\text { Lobectomy } \\
\text { Lobectomy } \\
\text { Local excision } \\
\text { Wedge resection } \\
\text { Enucleation from LLL } \\
\text { Lobectomy } \\
\text { Lobectomy } \\
\text { Pneumonectomy } \\
\text { Resection } \\
\text { Lobectomy } \\
\text { Subtotal lobectomy } \\
\text { Lobectomy } \\
\text { Wedge resection RML } \\
\text { Lobectomy }\end{array}$ & 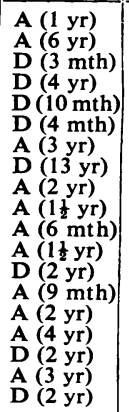 & $\begin{array}{l}\text { McCormack and Gallivan (1954) } \\
\text { Ochsner and DeCamp (1958) } \\
\text { Hess and Daum (1960) } \\
\text { McCormack et al. (1961) } \\
\text { Wojtowicz and Salwa (1962) } \\
\text { Braham et al. (1962) } \\
\text { Wellington and Neuman (1963) } \\
\text { Feldman and Seaman (1964) } \\
\text { Vidrine and Welsh (1964) } \\
\text { Sperling and Wendt (1965) } \\
\text { Rotte (1965) } \\
\text { Rotte (1965) } \\
\text { Krenz and Römer (1965) } \\
\text { Vecchioni et al. (1967) } \\
\text { Poulet et al. (1968) } \\
\text { Poulet } \text { et al. (1968) } \\
\text { Vasiliev and Stein (1969) } \\
\text { Jackson (1971) } \\
\text { Bruart et al. (1971) }\end{array}$ \\
\hline $\begin{array}{l}52 \\
23 \\
73 \\
53 \\
63 \\
70 \\
11 \\
10 \\
16\end{array}$ & $\begin{array}{l}\mathbf{F} \\
\mathbf{M} \\
\mathbf{M} \\
\mathbf{M} \\
\mathbf{F} \\
\mathbf{M} \\
\mathbf{M} \\
\mathbf{M} \\
\mathbf{M}\end{array}$ & $\begin{array}{l}\text { Asymptomatic } \\
\text { Asymptomatic } \\
\text { Dyspnoea, cough } \\
\text { Chest pain, haemoptysis } \\
\text { Asymptomatic } \\
\text { Chest pain, cough } \\
\text { Asymptomatic } \\
\text { Asymptomatic } \\
\text { Asymptomatic }\end{array}$ & $\begin{array}{l}\text { LLL } \\
\text { LLL } \\
\text { RLL } \\
\text { LUL } \\
\text { LLL } \\
\text { LUL } \\
\text { LUL } \\
\text { RUL } \\
\text { RML }\end{array}$ & $\begin{array}{r}2 \cdot 5 \\
3 \\
15 \\
14 \\
2 \cdot 5 \\
14 \\
6 \\
5 \\
4.5\end{array}$ & $\begin{array}{l}\text { Lobectomy } \\
\text { Segmental resection } \\
\text { Pneumonectomy } \\
\text { Pneumonectomy } \\
\text { Enucleation } \\
\text { Pneumonectomy } \\
\text { Lobectomy } \\
\text { Lobectomy } \\
\text { Lobectomy }\end{array}$ & $\begin{array}{l}\text { A }(-) \\
\text { A }(-) \\
\text { D }(5 \mathrm{mth}) \\
\text { D }(2 \mathrm{mth}) \\
\text { A }(3 \mathrm{yr}) \\
\text { D }(4 \mathrm{mth}) \\
\text { A }\left(1 \frac{1}{2} \mathrm{yr}\right) \\
\text { A }\left(-\frac{1}{1 \mathrm{yr}}\right) \\
\text { A }(1 \mathrm{yr})\end{array}$ & $\begin{array}{l}\text { Davis et al. (1972) } \\
\text { Padilla et al. (1972) } \\
\text { Present study } \\
\text { Marcinski and Trzebinski (1967) } \\
\text { Klimansky et al. (1969) } \\
\text { Itoh and Yoshiki (1970) }\end{array}$ \\
\hline
\end{tabular}




\section{TREATMENT}

Tumour excision is the treatment of choice for all primary haemangiopericytomata of the lung. Lobectomy, or pneumonectomy, as indicated by the extent of lung involvement, is preferred to enucleation, in view of the difficulty of assessing the malignant potential of this tumour and the high incidence of local recurrence.

Radiotherapy has not been used as the primary method of treatment because exploratory operations have been needed in all cases to provide tissue diagnosis. The results of radiotherapy when used for tumour in other regions of the body have been inferior to those of surgery (Backwinkel and Diddams, 1970).

The place of radiotherapy as an adjunct to surgery is not clear but it would appear to be a logical step at present if the surgeon believes that there has not been total extirpation of the tumour. Insufficient information is available for any balanced judgement to be made on the place of chemotherapy.

\section{PROGNOSIS}

There were four deaths in 16 female patients $(25 \%)$. This was a much lower mortality than the $66 \%$ in nine male patients. Examination of the results of treatment suggests that asymptomatic females with small tumours have a relatively favourable prognosis. Patients with symptoms, especially males with large tumours, appear to have a poor prognosis.

We wish to thank Mr. W. F. Nicholson for permission to include case 3, and Dr. J. Morrison for permission to include case 4. We are also indebted to Dr. M. Kay who provided us with Figs 14 and 15, and to Miss P. A. Hawkes for typing the manuscript.

\section{BIBLIOGRAPHY}

Agrawal, P. K. (1965). The cellular structure and development of the retinal vessels of the rat. Oriental Archives of Ophthalmology, 3, 23.

Ashton, N. and Oliveira, F. de (1966). Nomenclature of pericytes. British Journal of Ophthalmology, 50, 119.

Backwinkel, K. D. and Diddams, J. A. (1970). Hemangiopericytoma-report of a case and comprehensive review of the literature. Cancer, 25, 896.

Benninghoff, A. (1930). Blutgefässe und Herz In Handbuch der mikroscopischen Anatomie des Menschen. Edited by W. von Möllendorff, band 6, teil 1, pp. 1-232. Springer, Berlin.

Bensley, R. R. and Vimtrup, B. (1928). On the nature of Rouget's cells of capillaries Anatomical Record, 39, 37.
Bloodworth, J. M. B. (1963). In Soc. Proceeding-Conference on Microcirculation and Diabetic Retinopathy. American Journal of Ophthalmology, 55, 159.

Bogedain, W. and Carpathios, J. (1967). Therapy of haemangiopericytoma with pulmonary metastases. $\overparen{\Phi}$ J. Lancet, 87, 213.

Braham, J., Sarova-Pinchas, I., Pauzner, Y. M., and Braf, Z. ڤొ (1962). Haemangiopericytoma of the lung with metastasis $\vec{\circ}$ to the brain. Case report. Israel Medical Journal, 21, 47.

Bruart, J., Parmentier, R., Vanderhoeft, P., and Remacle, P. $\vec{\omega}$ (1971). A propos d'un cas d'hémangiopéricytome pulmonaire primitif associé à un syndrome de Klippel, $\underset{\vec{F}}{\vec{F}}$ Trenaunay, Parker, Weber. Journal Français de Médecine $\vec{x}$ et de Chirurgie Thoraciques, 25, 145.

Cotran, R. S., La Gattuta, M., and Majno, G. (1965). Studies on inflammation;--Fate of intramural vascular deposits induced by histamine. American Journal of $\mathrm{O}$ Pathology, 47, 1045.

Crocker, D. W. and Veith, F. J. (1965). Mesodermal tumors associated with hypoglycemia. Review of literature and report of a case. Annals of Surgery, 161, 418.

Davis, Z., Berliner, W. P., Weiland, L. H., and Clagett, O. T.乌 (1972). Primary pulmonary hemangiopericytomareport of a case. Journal of Thoracic and Cardiovascular $\vec{\theta}$ Surgery, 64, 822.

Eberth, C. J. (1871), Von den Blutgefässen. In S. Stricker (ed.)-Handbuch der Lehre von den Geweben des Menschen und der Thiere. Vol. 1, p. 191. Engelmann, Leipzig.

Equen, M., Roach, G., and Brown, R. (1963). Haemangio- ొّ pericytoma of lung found in search for corsage pin. Eye, Ear, Throat Monthly, 42, 34.

Feldman, F. and Seaman, W. B. (1964). Primary thoracic윽 hemangiopericytoma. Radiology, 82, 998.

Fernando, N. V. P. and Movat, H. Z. (1964). The fine structure of the terminal vascular bed-III: Capillaries. Experimental and Molecular Pathology, 3, 87.

Fisher, E. R., Kaufman, N., and Mason, E. J. (1952).으 Hemangiopericytoma-histologic and tissue culture® studies. American Journal of Pathology, 28, 653.

Friedman, M. and Egan, J. W. (1966). Irradiation of hemangiopericytoma of Stout. Radiology, 74, 721.

Hess, H. and Daum, R. (1960). Beitrag zum Thema Hämangiopericytome. Langenbecks Archiv für klinische? Chirurgie, 294, 75.

Herzog, G. (1914). Über adventitielle Zellen und über die Entstehung von granulierten Elementen. Verhandlungen der Deutschen Gesellschaft für Pathologie, 17, 562.

Hogan, M. J. and Feeney, L. (1963). Ultrastructure of retinal vessels. II small vessels. Journal of Ultrastructuren Research, 9, 29.

Itoh, T. and Yoshiki, T. (1970). Case of pulmonary haemangiopericytoma. Japanese Journal of Cancer Clinics, 16, 1111.

Jackson, J. (1971). Personal communication.

Kauffman, S. L. and Stout, A. P. (1960). Hemangiopericy toma in children. Cancer, 13, 695.

Kent, K. H. (1957). Hemangiopericytoma: report of a case with special reference to Roentgen therapy. American Journal of Roentgenology, 77, 347.

Klimansky, V. A., Shekhter, A. I. and Revzis, M. G. (1969) Primary lung tumours in children. Voprosy Onkologik, 15, No. 3, 9 . 
Krenz, M. (1971). Personal communication.

_ , and Römer, K. H. (1965). Mitteilung über ein Hämangioperizytom der Lunge. Deutsche Gesundheits wesen, $20,257$.

Krogh, A. and Vimtrup, B. (1932). The Capillaries: In Special Cytology. Edited by E. V. Cowdry. 2nd ed., Vol. 1, p. 475. Hoeber, New York.

Kuhn, C. and Rosai, J. (1969). Tumors arising from pericytes; ultrastructure and organ culture of a case. Archives of Pathology, 88, 653.

Kuwabara, T. and Cogan, D. G. (1963). Retinal vascular patterns: VI-Mural cells of the retinal capillaries. Archives of Ophthalmology, 69, 492.

Lee, M. R. (1971). Renin-secreting kidney tumours. Lancet, 2, 254.

Lipsett, M. B., Odell, W. D., Rosenberg, L. E., and Waldmann, T. A. (1964). Humoral syndromes associated with non-endocrine tumors. Annals of Internal Medicine, 61, 733.

Lowbeer, L. (1961). Hypoglycemia-producing extrapancreatic neoplasms; a review. American Journal of Clinical Pathology, 35, 233.

Majno, G. and Palade, G. E. (1961). The effect of histamine and serotonin on vascular permeability. An electron microscopic study. Journal of Biophysical and Biochemical Cytology, 11, 571.

Marchand, F. (1898). Üeber die bei Entzündungen in der Peritonealhöhle auftretenden Zellformen. Verhandlungen der deutschen pathologischen Gesellschaft, 1, 63.

Marcinski, A. and Trzebinski, A. (1967). Haemangiopericytoma pluca u dziecka 11-letniego. Polski Przeglad Radiologiczny, 31, 513.

Maximov, A. (1927). Bundegewebe und blutbildende Gewebe. In Handbuch der mikroscopischen Anatomie des Menschen. Edited by W. von Mollëndorf. Springer, Berlin.

McCormack, L. J. and Gallivan, W. F. (1954). Hemangiopericytoma. Cancer, 7, 595.

_-, McIsaac, W. M., Ragde, H., Groves, L. K., and Effler, D. B. (1961). "Functioning" pulmonary neoplasms: I. The carcinoid tumour. II. The hemangiopericytoma. Cleveland Clinic Quarterly, 28, 145.

Movat, H. Z. and Fernando, N. V. P. (1964). The fine structure of the terminal vascular bed. iv. Venules. Experimental and Molecular Pathology, 3, 98.

Mujahed, Z., Vasilas, A., and Evans, J. A. (1959). Hemangiopericytoma. A report of four cases with a review of the literature. American Journal of Roentgenology, 82, 658.

Murad, T. M., von Haam, E., and Murthy, M. S. N. (1968). Ultrastructure of a hemangiopericytoma and glomus tumor. Cancer, 22, 1239.

Murray, M. R. and Stout, A. P. (1942). The glomus tumor. Investigation of its distribution and behavior and the identity of its "epithelioid" cell. American Journal of Pathology, 18, 183.

O'Brien, P. and Brasfield, R. D. (1965). Hemangiopericytoma. Cancer, 18, 249.

Ochsner, S. and DeCamp, P. T. (1958). Hemangiopericytoma of lung. American Review of Tuberculosis, 77, 496.

Oliveira, F. de (1966). Pericytes in diabetic retinopathy. British Journal of Ophthalmology, 50, 134.

Padilla, J. M., Lain, A., Martinez, R., Rodriguez Padilla, F., and Martinez Muñoz, J. (1972). Hemangiopericitoma de pulmon. Revista Clinica Espanola, 125, 81 .
Paullada, J. J., Lisci-Garmilla, A., Gonzales-Angulo, A., Jurado-Mendoza, J., Quijano-Narezo, M., GomezPeralta, L., and Doria-Medina, M. (1968). Hemangiopericytoma associated with hypoglycemia; metabolic and electronmicroscopic studies of a case. American Journal of Medicine, 44, 990.

Poulet, J., Roujeau, J., Brux, J. de, Meyer, A., and Monod, O. (1968). Primary vascular tumours of lung. Journal français de Médecine et Chirurgie Thoraciques, 22, 645.

Roach, G. (1971). Personal communication.

Robertson, P. W., Klidjian, A., Harding, L. K., and Walter G. (1967). Hypertension due to a renin-secreting ren tumor. American Journal of Medicine, 43, 963.

Rotte, K. H. (1965). Ein Beitrag zum primären Hämangioperizytom der Lunge. Archiv für Geschwulstforschung 26, 95.

Rouget, C. (1873). Mémoire sur le développement, la structure et les propriétés physiologiques des capillaires sanguins et lymphatiques. Archives de physiologie normale et pathologique, 5, 603 .

(1874). Note sur le développement de la tunique contractile des vaisseaux. Comptes rendus hebdomadaires des Séances de l'Académie des Sciences, 79, 559.

(1879). Sur la contractilité des capillaries sanguines. Comptes rendus des séances de la Société de biologie et de ses filiales, 88, 916.

Salvadori, B. and Zingo, L. (1968). Studio di duo casi di emangiopericitoma. Tumori, 54, 489.

Shakib, M. and Oliveira, F. de (1966). Studies on developing retinal vessels. British Journal of Ophthalmology, 50, 124.

Silver, G. M. (1971). Personal communication.

Sperling, E. and Wendt, F. (1965). Hämangioperizytomatose der Lunge. Thoraxchirurgie, 13, 321.

Stout, A. P. (1956). Tumors featuring pericytes; glomus tumor and hemangiopericytoma. Laboratory Investigation, 5, 217.

- and Murray, M. R. (1942). Hemangiopericytoma Annals of Surgery, 116, 26.

Toker, C. (1969). Glomangioma; an ultrastructural study. Cancer, 23, 487.

Vasiliev, V. N. and Stein, L. F. (1969). Haemangiopericytoma of lung. Grudnaya Khirurgiya, 11, Nov.-Dec., p. 96.

Vecchioni, R., Cordiano, C., and Perrino, G. (1967). Hemangiopericytoma of lung. Acta Chirurgica Italica, 23, 545 .

Venkatachalam, M. A. and Greally, J. G. (1969). Fine structure of glomus tumour-similarity of glomus cells to smooth muscle. Cancer, 23, 1176.

Vidrine, A. Jr. and Welsh, R. A. (1964). Hemangiopericytoma-Five cases. Surgery, 56, 912.

Vimtrup, B. (1922). Beiträge zur Anatomie der Capillaren. I Über contractile Elemente in der Gefasswand der Blutcapillaren. Zeitschrift für Anatomie und Entwicklungsgeschichte, 65, 150.

Wellington, J. L. and Neuman, H. W. (1963). Primary hemangiopericytoma of the lung. Canadian Medical Association Journal, 88, 1295.

Wojtowicz, M. and Salwa, W. (1962). Häemangioperizytom der Lunge. Zentralblatt für Chirurgie, 87, 709.

Zimmermann, K. W. (1923). Der feinere Bau der Blutcapillaren. Zeitschrift für Anatomie und Entwicklungsgeschichte, 68, 29 